\title{
„Wiesnik Grodzienskaga dzierżaunaga uniwiersiteta imja Janki Kupaly”. Seria 1, sakawik 1999, nr 1, s. 96.
}

Uniwersytet w Grodnie rozpoczął wydawanie uczelnianego czasopisma naukowego. W słowie wstępnym „Do czytelników” w pierwszym numerze „Wiesnika” rektor tej uczelni, a jednocześnie redaktor naczelny, prof. S. A. Maskiewicz zwraca uwagę na fakt, że nowe czasopismo poprzedza 60-lecie uczelni i jest niejako dedykowane tej rocznicy. Faktycznie tamtejszy uniwersytet powstał 1 V 1978 r. jednak władze wywodzą jego genezę od Instytutu Nauczycielskiego, który rozpoczął działalność w mieście 7 III 1940 r., czyli w kilka miesięcy po zajęciu Grodna przez Armię Czerwoną i włączeniu w skład ZSRR.

Kwartalnik ma ukazywać się na przemian w dwóch seriach: humanistycznej i nauk ścisłych. Numer marcowy inauguruje serię humanistyczną obejmującą następujące dyscypliny: historię, filozofię, pedagogikę, psychologię, prawo, filologię oraz kulturoznawstwo, wiedzę o sztuce, politologię i socjologię. Redaktorem odpowiedzialnym tej serii (a także członkiem 5-osobowej Rady Redakcyjnej) jest znany historyk - prof. Aleksander Nieczuchryn.

Recenzowany numer zawiera 13 artykułów z sześciu pierwszych z wymienionych dziedzin, przy czym dominują: historia - 4 artykuły oraz prawo i filologia - po 3. Większość tekstów jest w języku rosyjskim (8), pozostałe (5) - w białoruskim. Każdy artykuł poprzedzony jest bardzo krótkim streszczeniem w jęz. angielskim, natomiast tuż przed spisem treści znajduje się omówienie wszystkich artykułów w jęz. rosyjskim, łącznie z podaniem ilości pozycji bibliograficznych, na które powołują się autorzy.

Kwartalnik otwiera interesujący artykuł Iwana Kowkiela na temat przygotowań do postawienia kwestii białoruskiej podczas konferencji genueńskiej w 1922 r., choć już w pierwszym zdaniu zdarzył się przykry błąd korektorski, gdyż podaje się, że konferencja ta odbyła się w dniach 10 IV - 19 V 1992 roku (!). Autor relacjonuje dalej wysiłki polityków białoruskich przebywających w Polsce i na Litwie, którzy starali się, niestety bezskutecznie, wykorzystać konferencję w Genui dla podjęcia sprawy narodowej.

W przypadku drugiego artykułu - „Dynamika i specyfika ruchu robotniczego w Zachodniej Białorusi (1921-1939)" - także pierwsze zdanie budzi zdziwienie, choć nie ze względu na usterki korektorskie. „Ruch robotniczy w Zachodniej Białorusi w okresie międzywojennym - pisze M. B. Siamionczyk - był nieodłączną częścią ruchu rewolucyjnego i narodowo-wyzwoleńczego w całej Polsce". Zdanie to brzmi jak z poprzedniej epoki. Wynika z niego, że autor utożsamia ruch robotniczy z ruchem komunistycznym, który w dodatku w całej Połsce walczył o wyzwolenie narodowe! M. B. Siamionczyk ma także problemy z określeniem obszaru „Zachodniej Białorusi", jako że wspomina nie tylko o Białymstoku i Sokółce, ale także o Augustowie i na- 
wet Łomży (s.15)ํ. Nie mógł też wykorzystać zespołu „Urząd Wojewódzki Białostocki” w Centralnym Archiwum MSW, ponieważ już kilkanaście lat temu został on przekazany najpierw do AAN, a następnie do Archiwum Państwowego w Białymstoku. Mało prawdopodobne jest też, aby w demonstracjach w Wilnie z okazji XI rocznicy rewolucji październikowej uczestniczyło około 1 tysiąca osób - być może była wówczas demonstracja, ale zapewne $\mathrm{z}$ innego powodu. Jak z bajki brzmi też informacja, że w dniach 21-30 I 1929 r. w Białymstoku strajkowali tkacze przeciwko wprowadzeniu 12-godzinnego dnia pracy (s.14).

Kolejny artykuł, W. A. Sabalewskiej, dotyczy tradycyjnej rodziny żydowskiej na ziemiach białoruskich na przełomie XVIII i XIX wieku, natomiast W. A. Biełozorowicz pisze o przekształceniach w rolnictwie w zachodnich obwodach Białorusi w latach 1949-1952. Okazuje się, że jeszcze na początku 1949 r. na tym obszarze skolektywizowanych było zaledwie 6,8\% gospodarstw indywidualnych. Początek lat pięćdziesiątych był okresem przyspieszonej kolektywizacji połączonej z ostrymi represjami wobec opornych. Tylko w 1952 r. poza granice republiki wysiedlono 4431 rodzin „kułackich”. Autor nie jest jednak jeszcze w stanie dokonać pełnej syntezy i podać np. ogólną liczbę osób represjonowanych z tego powodu. Pewne zdziwienie budzi streszczenie artykułu, w którym stwierdza się, że to potrzeba uprzemysłowienia kraju, połączona z koniecznością odbudowy zniszczonej wojną gospodarki, postawiła problem masowej kolektywizacji.

W „Wiesniku” brak jest innych działów, zazwyczaj znajdujących się w czasopismach naukowych, jak np. źródła i materiały, recenzje, informacje itp. Brakuje też krótkich notek o autorach - będzie to istotne zwłaszcza wtedy, jeśli zaczną publikować swoje artykuły w tym kwartalniku osoby spoza Uniwersytetu Grodzieńskiego. Na końcu redakcja zamieszcza zasady przygotowania artykułów do druku - dosyć szczegółowe (łącznie z podaniem wielkości czcionki) - i uwagę, że nie wolno wnosić poprawek w stosunku do złożonego już oryginału. Cały numer ma około 10 arkuszy drukarskich, przy czym 1/3 miejsca zajmują teksty poświęcone historii.

Jan Jerzy Milewski

${ }^{1}$ Większość historyków białoruskich ma problemy z określeniem obszaru tzw. „Zachodniej Bialorusi”. Zwracam na to uwagę w artykule: Zachadniaja Bielaruś: da pytanija terytoryi i nasielnictwa, „Biełaruski Gistaryczny Czasopis", 1998, nr 3. 